Д. А. Лопатин, Н. Г. Юдина // Матер. 5 Всероссийского съезда судебных медиков: - М.: ВОСМ. - 2000.-С. 46-47.

9. Мішалов В.Д. Недоліки і проблеми організації судово-медичних заходів в умовах надзвичайних ситуацій 3 масовими жертвами людей в Україні / В. Д. Мішалов, О. І. Герасименко, В. В. Войченко, Г. А. Зарицький // Збірник наукових праць НМАПО імені П. Л. Шупика. - Київ. - 2009. - Вип. 16. - Книга 3. - С. 74-80.

10. Пашинян Г.А., Тучик Е.С. Судебно-медицинская экспертиза при крупномасштабных катастрофах. - Москва, 1994. - 136 с.

11. Ракитин В. А. Опыт идентификационных ДНК-исследований в случаях массовой гибели людей / В. А. Ракитин, А. В. Волков, И. В. Корниенко // Матер. УІ Всероссийского съезда судебных медиков. - Москва-Тюмень. - 2005. - С. 233-235.

12. Тучик Е. С. Некоторые вопросы организации судебно-медицинской экспертизы в чрезвычайных ситуациях / Е. С. Тучик // Судебно- медицинская экспертиза. - 1993. - № 3. - С. 33-35.

13. Хоменок Ю. В. Методические рекомендации по идентификации личности в случаях авиационных происшествий. Киев, 1978.-15 с.

14. Щербакова Е. В. Алгоритм компьютеризированного анализа молекулярно-генетических данных для решения задач идентификации личности по исходам событий с массовыми человеческими жертвами /

Е. В. Щербакова, В. В. Щербаков, П. Л. Иванов // Судебно-медицинская экспертиза. -2005. - № 1. - С. 21-24.

15. Звягин В. Н. Медико-криминалистическое исследование фрагментов тел при массовом поступлении трупов / В. Н. Звягин, О. И. Галицкая, М. А. Негашева // Судебно-медицинская экспертиза. - 2012. - №2. - Т. 55. - С. 4-10.

16. Звягин В. Н. Биометрическая сортировка трупов, разрушенных в очаге катастрофы, по признакам пола, продольным, обхватным размерам и степени подкожных жироотложений / В. Н. Звягин, О. И. Галицкая, М. А. Негашева // Судебно-медицинская экспертиза. - 2012. - №3. - Т. 55. - С. 4-8.

\title{
A COMPREHENSIVE APPROACH FOR THE FORENSIC IDENTIFICATION OF VICTIMS DURING ARMED CONFLICTS AND DISASTERS
}

\author{
Voichenko V.V., Mishalov V.D., Mamedov Sh.M.o., Vyun V.V., \\ Ivashyna A. H.
}

Summary. The article presents current issues on the organization of forensic services in the identification of dead people in emergencies with mass victims of people in Ukraine.

Keywords: emergency, massive loss of life, comprehensive approach in conducting forensic identification.

УДК 343.226:646-053.2/.5:17(070)

\section{СУДОВО-МЕДИЧНА ОЦІНКА ПРОЯВІВ ЗАПОДІЯННЯ КАТУВАНЬ І МОРДУВАНЬ ТА ШЛЯХИ ЇХ ЕФЕКТИВНОЇ ДОКУМЕНТАЛЬНОЇ ФІКСАЦІї У ФОРМАТІ «СТАМБУЛЬСЬКОГО ПРОТОКОЛУ»}

\author{
СВойченко В. В. ${ }^{1}$, Мішалов В. Д., ${ }^{2}$ В’юн В. В., ${ }^{1}$ Валіахметов Д. А. ${ }^{3}$
}

КЗ «Дніпропетровське обласне бюро судово-медичної експертизи» ДОР ${ }^{1}{ } »$ Національна медична академія післядипломної освіти імені П. Л. Шупика ${ }^{2}$ Київське міське клінічне бюро судово-медичної експертизи ${ }^{3}$

Резюме. У статті наведена судово-медична оцінка деяких проявів заподіяння катувань і мордувань та інших жорстоких, нелюдських або таких, що принижують гідність, видів поводження і покарання та шляхи їх ефективної документальної фіксації у відповідності до положень «Стамбульського протоколу».

Ключові слова:судово-медична експертиза, катування, мордування, «Стамбульський протокол»

ВСТУП. Гарантованість прав та свобод громадян є рисою відзнаки конституційного статусу і держава розглядає це як свій первинний обов'язок. Кожна людина повинна знати та мати віру, що хто б не зчинив шкоди їі здоров’ю - винні завжди понесуть незворотну кару за законним порядком, що іії воля та права це не тільки слова, а $є$ реальність.

Конвенція проти катувань та інших жорстоких, нелюдських або таких, що принижують гідність видів поводження і покарання, була прийнята Генеральною Асамблеєю Організації Об’єднаних Націй 10 грудня 1984 року і складена із 33 статей. Конвенція набрала чинності 26 червня 1987 року.

«Стамбульский протокол» - керівництво по ефективному розслідуванню і документуванню катувань та інших жорстоких, нелюдських або принижуючих гідність видів поводження і покарання» http://www.ohchr. 
org/Documents/Publications/training8Rev1ru.pdf [1] - був представлений Верховному комісару ООН по правам людини 9 серпня 1999 р. Дане керівництво призване служити міжнародним принципам оцінки дій осіб, які застосовують катування і тортури або жорстоке поводження по відношенню до людей, а також для розслідування випадків катувань та інших жорстоких, нелюдських або принижуючих гідність видів поводження і передання звітів до слідчих, судових або інших органів. Методи документування, що містяться в даному керівництві, можуть бути використані і в інших випадках, включаючи розслідування і контроль дотримання прав людини, оцінки необхідності політичного притулку, осіб, що «призналися» у здійсненні злочину під тортурами і катуванням, оцінки поводженнями 3 жертвами катувань і інш. До керівництва додаються принципи ефективного розслідування і документування катувань і жорстокого поводження, а також керівництво з медичної оцінки i документування катувань і жорстокого поводження представниками офіційної влади (зокрема правоохоронних органів) з особою під час їі арешту, запровадження до СІЗО або у місцях пенітенціарної системи.

На превеликий жаль, ще й сьогодні, після реорганізації колишньої міліції в сучасну “поліцію”, мають місце прояви старих звичок - поводження до громадянина як до істоти, яка споконвічно, заздалегідь позначена печаткою вини. Поліцію офіційно називають правоохоронним органом, забуваючи при цьому, що насамперед, це має бути орган захисту здоров'я, гідності і честі людини, а права людини охороняти не потрібно - їх треба суворо дотримуватись.

Доводиться визнати, що окремі охоронці порядку і сьогодні мають хибну уяву щодо свого високого призначення. Вони, не замислюючись про наслідки, легко переступають межу, за якою починається беззаконня, грубе порушення прав людини. Тому тут слід було б нагадати про Аксіому Дж. Мілля: «Те, що відбулося один раз, буде обов'язково мати місце, як тільки знову створяться ті ж самі умови».

Метою дослідження було висвітлення судово-медичних проявів заподіяння катувань і мордувань та шляхи їх ефективної документальної фіксації у форматі «Стамбульського протоколу».

Матеріал і методи дослідження. Для реалізації поставленої мети були використані архівні матеріали КЗ «Дніпропетровське обласне бюро СМЕ» ДОР». Зокрема, за 2016 рік судово-медичними експертами бюро CME було проведено 36 експертиз та обстежень 3 приводу нанесення тілесних ушкоджень працівниками правоохоронних органів і 70 експертиз було проведено по СІЗО. Мова йде про невиправдане насильство так званих «правоохоронців» над затриманими. В роботі були використані стандартні судово-медичні та статистичні методи дослідження.

\section{РЕЗУЛЬТАТИ ДОСЛІДЖЕННЯ ТА ЇХ ОБГОВОРЕННЯ.}

Як відомо, способами спричинення насильницьких дій (катування, тортури, мордування) внаслідок фізичного та психічного впливу можуть бути наступні:

1. Тортури сигаретами. Використання шкіри людини в якості попільнички дуже болюча процедура, яка тішить слух катів гучними криками жертви.

2. Затискання нігтів. Пальці поміщають в підручні і спеціальні пристрої.

3. Побиття, що не залишало слідів. Б’ють підслідних лінійками, мішками з піском, по нирках, печінці і навіть по чоловічим статевим органам.

4. Тортури комахами. Можуть зв'язавши, посадити на мурашник.

5. Тортури звуком. Жертву змушують голосно відповідати на всі питання. Або підходять впритул і кричать на вухо. Гучні звуки можуть призвести до втратити слуху.

6. Тортури світлом. У камері постійно включено дуже яскраве світло. Таке ж світло направляють в обличчя підслідному і на допитах. Від тривалої дії яскравого світла очі сльозяться, затуманюється свідомість.

7. Тортури голодом. Після 10-15 діб примусового голодування ув'язнений готовий практично на все.

8. Тортури спрагою. Ту ж саму жертву можуть навіть нагодувати - але обов'язково дуже солоною їжею, щоб пити хотілося сильніше.

9. Тортури безсонням. За впливом нагадує тортури світлом і може застосовуватися разом з нею. Починаються галюцинації і головні болі.

10. Череда допитів. Людину періодично приводять на допити і повертають назад. Вона постійно знаходиться в тривожному стані, нервує і рано чи пізно зривається.

11. Ластівка. Жертві проводять через зуби (на зразок кінської вузди) шматок мотузки або міцної тканини, а кінці прив'язують до ніг. Жертва не може ні ворушитися, ні кричати.

12. Замикання в шафу або ящику. Кілька годин перебування в тісній замкненій коробці, в якій можна було або тільки стояти, або тільки сидіти, діє на жертву ще гірше, ніж побиття. У ніші людина, як правило, відчуває себе не просто замкненою, а практично замурованою заживо.

13. Замикання в карцері. У цих тюремних приміщеннях низька температура, а нерідко до холоду додавалася ще і висока вологість. Три-п'ять днів у карцері можуть зіпсувати людині здоров'я на все життя.

14. Яма. Ув'язненого можуть помістити не лише в закритий простір. 
15. Відстійник. У тісному приміщенні («відстійнику») кілька людей впритул замикають на тривалий термін.

16. «Стілець». Жертву змушують перебувати в сидячому положенні на стільці над дошкою з цвяхами або битим склом.

17. Табуретка. Людину саджають на табуретку і не дають рухатися кілька годин. Поворушишся - б’ють. Сидіння без руху призводить до затікання м'язів, починають боліти ноги і спина.

18. Тортури на колінах. Тривале стояння на колінах перед слідчими або охоронцями дає не тільки фізичне навантаження, але й чинить шалений тиск на психіку.

19. Тортури стоянням. Весь час змушують підслідного стояти, не даючи ні притулитися до стіни, ні присісти, ні заснути.

20. Тортури згвалтуванням. Досить стандартний варіант тортур жінок.

Слід зауважити, що нелюдській винахідливості в тортурах немає меж, про що нами повідомлялось раніше в публікації «Визначення понять і систематизація насильницьких дій шляхом нанесення побоїв, заподіяння мордувань і катувань» [2].

При цьому, доцільним, на наш погляд, є звернення уваги на визначення термінів у КК України [3], що стосуються вибраної нами теми:

- Побої і мордування (ст. 126 КК України) - умисне завдання удару, побоїв або вчинення інших насильницьких дій, які завдали фізичного болю і не спричинили тілесних ушкоджень. Вони спрямовані на заподіяння тривалого болю.

- Катування (ст. 127 КК України) - умисне заподіяння сильного фізичного болю або фізичного чи морального страждання шляхом нанесення побоїв, мучення або інших насильницьких дій 3 метою спонукати потерпілого або іншу особу вчинити дії, що суперечать їх волі.

- $\quad$ Тортури або катування - будь-яка процедура, що заподіює людині муки і біль, незалежно від обставин і цілей, незалежно від того, чи закінчується покарання цією процедурою або за нею слідує позбавлення людини життя (Вікіпедія).

- Мучення (або заподіяння мук) - це насильницькі дії, пов'язані з тривалим позбавленням їжі, пиття чи тепла, утримання в шкідливих для здоров’я умовах.

Отже, відповідно до Кримінального кодексу України, побої, мордування і катування осуджуються відповідними статтями і передбачають покарання.

Особливість «Стамбульського протоколу» полягає у тім, що в ньому наведений окремий наголос надважливості проведення фізичного та психологічного обстеження потерпілих, що зазнали катувань під час арешту. Обов' язкове запровадження до СІЗО або у місцях пенітенціарної системи, виконання діагностичних аналізів і ведення документації за єдиними формами та в розумні строки: “...Медична експертиза має бути проведена незалежно від часу, який минув після катувань; проте, якщзо заявник стверджує, щзо це сталося протягом останніх шести тижнів, така експертиза має бути організована невідкладно, пери ніж зникнуть явні сліди катувань... ”.

3 медичної точки зору, тілесні ушкодження - це порушення анатомічної цілості тканини, органів та їх функцій, що виникає як наслідок дії одного чи кількох зовнішніх ушкоджуючих факторів - фізичних, хімічних, біологічних, психічних... Слід зауважити, щзо мучення $і$ мордування не є особливим видом ушкоджень, а лише свідчать про особливості їх походження чи спосіб нанесення.

Відповідно до чинного українського законодавства “...Судово-медична експертиза проводиться згідно 3 постановою особи, що проводить дізнання, слідчого, прокурора, судді, а також за ухвалою суду...» $[3,4]$.

Результати судово-медичної експертизи оформляються документом, який має назву «Висновок експерта». Структура цього документа визначається «Правилами проведення окремих видів експертиз», що затверджені наказом МОЗ України № 6 від 17 січня 1995р.[5].

Судово-медичне визначення ступеня тяжкості тілесних ушкоджень проводиться згідно з Кримінальнопроцесуальним кодексом України і «Правилами проведення окремих видів експертиз», що затверджені наказом МО3 України № 6 від 17 січня 1995р.

Судово-медична експертиза з метою встановлення наявності та ступеня тяжкості тілесних ушкоджень проводиться судово-медичним експертом шляхом медичного обстеження потерпілих. Проведення цієї експертизи тільки за медичними документами (історія хвороби, індивідуальна карта амбулаторного хворого тощо) допускається у виняткових випадках і лише за наявності справжніх повноцінних документів, щомістять вичерпні дані про характер ушкоджень, їх клінічний перебіг та інші необхідні відомості.

Для реалізації положень «Стамбульського протоколу» у повсякденній практиці бюро судово-медичної експертизи України ми наголошуємо на наступних шляхах і формах ефективної документальної фіксації проявів заподіяння катувань і мордувань та інших жорстоких, нелюдських або таких, що принижують гідність, видів поводження і покарання.

Роль медичної документації. Для проведення експертизи й отримання обгрунтованого висновку важливе значення має оцінка результатів медичного обстеження потерпілого та вивчення відповідної медичної документації. Усю медичну документацію розглядають як доповнення до основного дослідження живої осо- 
би. Висновок судово-медичної експертизи безпосередньо залежатиме від якості й повноти наданої медичної документації. Проте особи медичного персоналу, які оформлюють таку документацію, не звертають уваги на значну кількість дрібних, з медичної та лікувальної точок зору, але важливих у криміналістичному й судово-медичному розумінні деталей, які мають істотне значення для встановлення істини. Це пов'язано $з$ тим, що в медичних документах зазвичай відображають лише найважливіші особливості ушкоджень. Водночас, локалізацію, кількість і характер дрібних ушкоджень, що не впливають на клінічну картину хвороби і лікування хворого, як правило, не беруть до уваги і не відображають у медичній документації. А дрібні, на перший погляд, прогалини в характеристиці тілесних ушкоджень можуть стати серйозними причинами помилки в установленні їх характеру й тяжкості.

Типовими недоліками у веденні й оформленні медичної документації, в якій фіксують стан хворого, перебіг хвороби, встановлення діагнозу та динамік хворобливих процесів тощо, є:

- неповне, а інколи суперечливе, описання стану хворого, виявлених проявів хворобливого стану органів $i$ систем;-недостатнє, а інколи й повністю відсутнє, описання в документаиії морфологічних ознак ран, ранових каналів, навколишніх тканин, підміна описання ушкоджень формулюванням діагнозу захворювання;

- неадекватність діагнозу й відсутність в історії хвороби його клініко-діагностичного обтрунтування.

Зазначені дефекти в оформленні документаціїпризводять до того, щосудово-медичнийекспертнеможевідповісти на всіпоставлені перед ним запитанняпроцесуальної особи, якоюпризначеносудово-медичнуекспертизу.

Фотографування потерпілих має своєю метою одержати протокольно-достовірний, наочний матеріал, який додається до відповідних слідчих і судово-медичних документів (протоколів оглядів і актів експертиз). Одержані при цьому фотографії, повинні наочно підтверджувати, а іноді й доповнювати дані, викладені у зазначених документах.

Використання фотографічної зйомки у відповідних випадках зумовлено такими чинниками:

1. Дає змогу з великою точністю зафіксувати об'єкт (ушкодження), його стан, ознаки.

2. Забезпечує швидке фіксування тих, чи інших об'єктів.

3. Дає адекватне уявлення про зображений на фотознімку об'єкт.

4. Існує певна можливість одержати малопомітні і невидимі візуально деталі, сліди, ознаки.

Для того, щоб такі фотографії могли відповідати своєму призначенню, їх треба виконувати з дотриманням певних правил:

1. Фотографувати завжди з масштабом - лінійка з поділками (мм), бажано, з шкалою кольорів.

2. Масштаб необхідно завжди розташовувати в одній площині (на одному рівні) з об'єктом.

3. Масштаб не повинен перекривати об'єкт дослідження.

4. Доцільно брати за правило - масштаб завжди розташовують доверху від ушкодження на тілі.

5. При фотозйомці ушкоджень необхідно щоб в поле зору входила розпізнана частина тіла.

6. Зафіксована площина тіла та площина об’єктиву повинні бути паралельні один до одного.

7. Знімок повинен бути сігналітичним (відкрите обличчя), при понівечені його - вушна мушля.

8. Фотозйомку вести з фотоспалахом (слідкуйте за відблисками світла на об'єкті та на масштабі).

9. Збоку від об'єкту розташуйте з назвою та датою будь-яку сьогоденну газету.

10. Вказати в протоколі умови фотозйомки (час доби, вид освітлення /штучне, змішане, природнє, з фотоспалахом/, погодні умови /ясно, хмарно/, пристрій, яким проводилась зйомка).

Відтворення графічних зображень тілесних ушкоджень на контурних схемах та базових 3D моделях тіла людини.

Засновник Харківської школи судових медиків, Заслужений професор Микола Сергійович Бокаріус в 1930 році наголошував на те, що які б детальні записи тілесних ушкоджень не були в протоколі експертного дослідження, та якою-б кількістю фото світлин не доповнювався цей протокол, не завжди все це дає повноту наглядного уявлення про загальну кількість пошкоджень, їх характер, форму, розміри, взаємне розташування, тощо.

Схема, є універсальним зоровим образом, своєрідною моделлю, яка лаконічно вбирає в себе, інтегрує та наглядно демонструє значний об'єм судово-медичної інформації і фіксує чисельну кількість інших різних фактів. 3 такою моделлю зручно працювати: аналізувати встановлені різнопланові дані, узагальнювати їх, умоглядно вибудовувати складні багатоланкові ланцюги логічних міркувань, роздумів, розсудів, i, в результаті, дозволяє прийти до вірних науково обгрунтованих переконливих експертних висновків.

Експерти на свій розсуд вибирають різні прийоми розміток, позначень, надписів на схемах (рис. 1 а,б). Зазвичай застосовують наступні розмітки тілесних ушкоджень: синці - синім кольором; садна, подряпини - коричневим; рани - червоним; опіки - рожевим; переломи - чорним кольором. Обов'язково на схемі слід надати роз'яснення умовних позначень. Бажано максимально наближено графічно відтворити форму ушкоджень, їх пропорційність. Обов’язково вказати не менше як два лінійних розміри ушкодження (в см). 


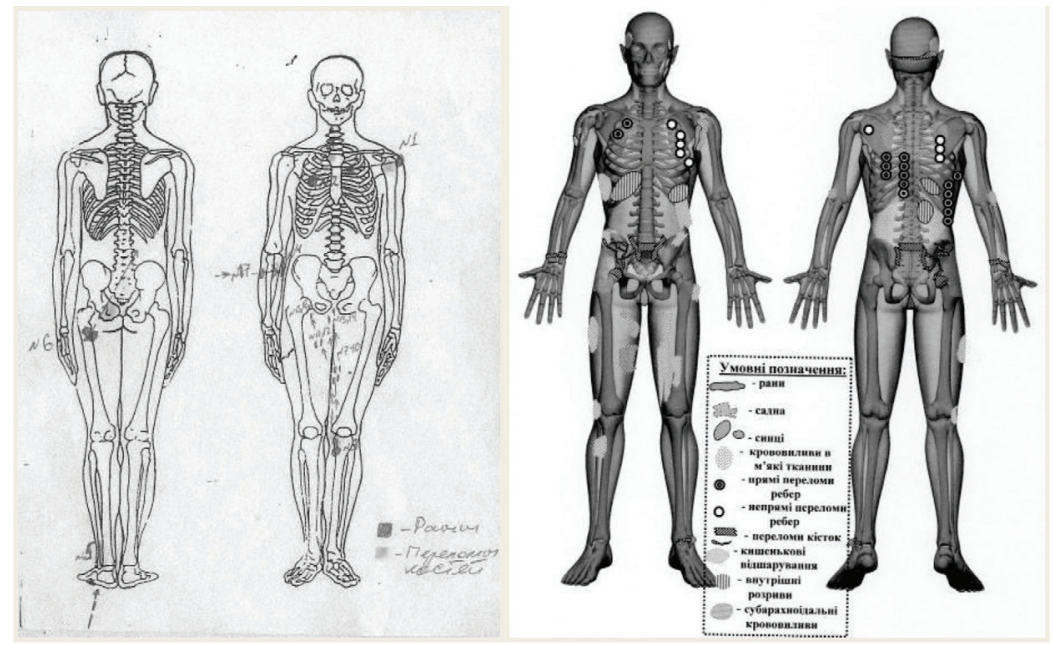

Рис.1. Графічне зображення тілесних ушкоджень на контурних схемах (а) і на базових 3D моделях (б) тіла людини.

Для ефективного розслідування та документальної фіксації тортур слід пам'ятати про наступні важливі обставини:

1. Встановлення факту і способів лікування /самолікування або лікарське втручання/ тілесних ушкоджень (мазі, примочки, фізіопроцедури і т.д).

2. Пам’ятати, що ушкодження /синці/ можуть проявлятися пізніше /повторний огляд через 2-3 дня /, а також «мігрувати» / переміщатися /.

3. Обов'язково відзначати функціональні розлади /обмеження руху в суглобах, перевірку зору, слуху, нюху, голосу /.

4. Застосування додаткових діагностичних лабораторних методів обстеження / Ro-графія, комп'ютерна томографія, ультразвукова діагностика, магнітно-резонансна візуалізація, ЕХО-енцефалограми, аналізи крові і сечі і т.д./.

5. Застосування електрошоку навіть 3 допустимими величинами вольтажа може у кардіологічних хворих викликати тяжкі розлади життєвих функцій і спричинити смерть.

6. При травмуванні електрошокером можливим $\epsilon$ викришування зубів, прикусування язика, губ, слизових порожнини рота. При ураженні струмом необхідна біопсія вказаних ділянок. На шкірі електроміткі слабо помітні, можуть бути замасковані саднами.

7. При заштовхуванні в порожнину рота різних предметів /кляпів / можуть пошкоджуватися зуби, слизова оболонка губ, ясен.

8. При асфіксії: виявляти на шиї слабопомітні смуги странгуляцій, дугоподібні дрібні садна від нігтів, рентгенологічний пошук переломів хрящів гортані, під’язикової кістки, встановлення функціонального порушення голосу /осиплість/; при закритті отворів рота і носа можуть спостерігатися садна крил носа, крововиливи слизових губ; пошук загальноасфіксичних ознак - дрібнокрапкові крововиливи шкіри обличчя, в слизові оболонки очей, одутлість обличчя / екхімози Тардьє /.

9. При тупий травмі переломи ребер можуть бути віддалені від місця прикладання сили / поза місцем локалізації саден, синців /.

10. Пам'ятати про травматичне облисіння, видалення нігтів, вивихи зубів.

11. Зберігати одяг /прати, рвати не можна/. Одяг цінне / і ноді єдине / джерело інформації.

12. Пам'ятати, що краще мати фотодокументи низької якості, замість ніяких.

13. У протоколах вказувати умови, при яких проводиться обстеження: час /години, хвилини/, де /в якому приміщенні /, погодні умови /ясно, похмуро/, освітлення /природнє, штучне, змішане, лампи накалювання, люмінесцентні або комбінація /, характеристика відео-, фотообладнання.

Важливо зазначити, що з 2016 р. у навчальний план та програму спеціалізації (інтернатури) з фаху «судово-медична експертиза» кафедри судової медицини Національної медичної академії післядипломної освіти імені П. Л. Шупика запроваджені основні положення «Стамбульського протоколу». Реалізація програми передбачає оволодіння майбутніми судово-медичними експертами основних положень «Стамбульського протоколу», методами діагностики, фіксації, опису та ефективної документації тілесних ушкоджень у випадках виявлення ознак (проявів) заподіяння катувань і мордувань та інших жорстоких, нелюдських або таких, що принижують гідність видів поводження і покарання з базовим розумінням взаємозв'язку між здоров'ям і правами людини. 
ВИСНОВОК. Отже, для ефективного розслідування катувань та інших жорстоких, нелюдських або принижуючих гідність особи під час іï арешту, запровадження до СІЗО або у місцях пенітенціарної системи, слід проводити їх якісну документальну фіксацію шляхом об'єктивної оцінки результатів медичного обстеження потерпілого та вивчення відповідної медичної документації, використання фотографічної зйомки, відтворення графічних зображень тілесних ушкоджень на контурних схемах та базових 3D моделях тіла людини, застосування додаткових діагностичних лабораторних методів обстеження / Rо-графія, комп'ютерна томографія, ультразвукова діагностика, магнітно-резонансна візуалізація, ЕХО-енцефалограми, аналізи крові і сечі і т.д., дотримуючись такого правила: чим більше об'єктивних даних, тим доступнішим є встановлення істини.

\title{
Література
}

1. Стамбульский протокол. Руководство по эффективному расследованию и документированию пыток и других жестоких, бесчеловечных или унижающих достоїнство видов обращения и наказания, 1999. - 113 с.

2. Визначення понять і систематизація насильницьких дій шляхом нанесення побоїв, заподіяння мордувань $\mathrm{i}$ катувань / В.Д.Мішалов, М. М. Тагаєв, В. В. Хижняк, А. О. Моргун// Судово-медична експертиза. - 2015. №1. - С. 8-19.

3. Кримінально-процесуальний кодекс України. Вид-во «Центр учбової літератури». - Київ, 2012. - 290 с.

4. Кримінально-процесуальний кодекс України. Науково-практичний коментар: у 2 т. /О.М. Бандурка, Є.М. Блажівський, Є.П. Бурдоль та ін.; за заг. ред. В.Я. Тація, В.П. Пшонки, А.В. Портнова. - Харків: «Право», 2012. Т. 1. - 768 с.

5. Наказ МОЗ України “Про розвиток та вдосконалення судово-медичної служби України” від 17 січня 1995 року № 6.

\section{СУДЕБНО-МЕДИЦИНСКАЯ ОЦЕНКА ПРОЯВЛЕНИЙ ПРИЧИНЕНИЯ ПЫТОК И ПУТИ ИХ ЭФФЕКТИВНОЙ ДОКУМЕНТАЛЬНОЙ ФИКСАЦИИ В ФОРМАТЕ «СТАМБУЛЬСКОГО ПРОТОКОЛА»}

\author{
Войченко В. В., Мишалов В. Д., Вьюн В. В., Валиахметов Д. А.
}

Резюме. В статье приведена судебно-медицинская оценка некоторых проявлений причинения пыток и других жестоких, бесчеловечных или принижающих достоинство видов обращения к личности и пути их эффективной документальной фиксации в соответствии с положениями «Стамбульского протокола».

Ключевые слова: судебно-медицинская экспертиза, пытки, истязания, «Стамбульский протокол».

\section{FORENSIC MEDICAL EVALUATION MANIFESTATIONS INFLICTION OF TORTURE AND TORTURE AND EFFECTIVE WAYS OF FIXATION DOCUMENTED IN THE «ISTANBUL PROTOCOL»}

\author{
Voichenko V., Mishalov V., Vyun V., Valiachmetov D.
}

Summary. In the article the forensic evaluation of certain manifestations of torture and infliction of torture and other cruel, inhuman or degrading Degrading Treatment or Punishment and effective ways of fixing the documentary under the provisions of «Istanbul Protocol».

Keywords: forensic examination, torture, «the Istanbul Protocol». 